\title{
Rhizosphere competent Pseudomonas indoloxydans (F3-47) as a plant growth promoter and enhancer of Zea mays L. under greenhouse and field trials
}

\author{
Reena Josephine.C.M ${ }^{1}$, Jibu Thomas ${ }^{2 *}$ \\ 1Department of Life Sciences, Kristu Jayanti College (Autonomous), K. Narayanapura, Kothanur (PO), \\ Bengaluru-560077
}

${ }^{2}$ Algae Biomass Research Laboratory, Department of Biosciences and Technology, Karunya Institute of Technology and Sciences, Coimbatore-641114, Ph: +91 4222614497

*Corresponding author: jibuthomas.t@gmail.com

\begin{abstract}
A rhizospheric bacterium belonging to the genus Pseudomonas isolated from the rhizosphere of maize was evaluated for the plant growth promoting and biocontrol traits. The strain was subjected to the different PGP and biocontrol traits such as ammonia, IAA, siderophores, phosphate solubilisation, ACC deaminase, HCN production, cellulase, pectinase and chitinase activity. 16S rRNA sequencing showed maximum homology with the strain Pseudomonas indoloxydans IPL-1(NR115922). In vivo plant growth promotion assay with the strains on maize seedlings showed a significant increase in the biometric parameters with respect to the number of shoots $(32 \%)$ and roots $(27 \%)$ and its fresh weight $(20 \%)$ and dry weight (54\%). Different formulations of the strain tested in fields revealed that the maize plants treated with the talc and lignite formulations showed a considerable increase in the growth of maize when compared to the plants without any treatment. The study concluded that the rhizosphere strains Pseudomonas indoloxydans (F347 ) could be a potential plant growth promoter for future exploration in agriculture.
\end{abstract}

Key words Pseudomonas indoloxydans, seed bacterization, talc, lignite, agriculture

\section{Introduction}

Due to urbanization and indiscriminate deforestation the land for cultivation is rapidly declining, giving rise to food insecurity. In order to meet the increasing demand by the increasing global population, alternative methods to increase food production is being sought. The method of uncontrolled application of chemical fertilizers and pesticides though increases the yield and controls the insects and pests, hazardous drawbacks with these chemicals by the continued application declines soil fertility, death of the normal microflora, soil erosion and contamination of the ground water bodies. To combat these problems, scientists are diverting their attention to the viable methods of crop protection (17).

Plant growth promotion with beneficial microorganisms is an ecofriendly option to increase crop yield and prevent outbreaks of pathogenic bacteria (7) that acts either by direct or indirect mechanisms. Direct promotion is through asymbiotic nitrogen fixation, synthesis of the auxins like indole acetic acid (IAA), gibberellins and cytokinins (29) and solubilisation of phosphates (31). Indirect promotion is through sequestering $\mathrm{Fe}^{3+}$ by producing siderophores, as well as cyanides that are antagonists to the plant pathogens. Strains of the genera Bacillus, Pseudomonas, Enterobacter, Azotobacter, Azospirillum, Bradyrhizobium, Actinobacter etc. are widely being used as biofertilizers (37). But, more often proliferation and soil establishment is limited to indigenous strains.

Among these, the genus Pseudomonas is well studied due to its usefulness as a plant growth promoting and biocontrol agent with multifaceted beneficial traits. These strains are known to exert an antagonistic activity by secreting different antibiotic compounds $(20,39)$. In addition they also produce ammonia, phosphate, siderophores, and cell wall degrading enzymes. Due to these versatile mechanisms of action the use of PGPR in the field of biofertilisation and biocontrol has become essential. Hence, the present study described the isolation and screening of the plant growth promoting abilities of native Pseudomonas from the rhizosphere of maize which was identified using 16S rRNA sequencing as Pseudomonas indoloxydans. The strain was subjected to field trials as different formulations to determine its effectiveness on the growth of maize, a major cereal crop after rice and wheat. The particular strain identified belongs to a species of Pseudomonas that has not been widely explored as PGP agent.

\section{Materials and methods}

\section{Sample collection and isolation of the organism}

Rhizosphere soil samples were collected from maize fields near the roots of the plants $(5-15 \mathrm{~cm})$ and also by uprooting the plants. They were stored in sterile polythene bags at $4^{\circ} \mathrm{C}$ until use. Soil suspensions were prepared $(10 \mathrm{~g} / 100 \mathrm{ml}$ in sterile distilled water), serially diluted (upto $10^{-6}$ ) and $0.1 \mathrm{ml}$ of the sample were plated on nutrient agar. Plates were incubated at $37^{\circ} \mathrm{C}$ for $24 \mathrm{hrs}$. Mucoid colonies with slight elevation and pigmentation was selected, pure colonies obtained in nutrient agar slants and maintained as glycerol stock at $-20^{\circ} \mathrm{C}$.

\section{Screening of the test strain for in vitro plant growth promoting and biocontrol traits}

\section{Ammonia, phosphate, IAA, siderophores}

The ability of the strain to fix atmospheric nitrogen was determined by the ammonia production test of 
Cappucino and Sherman (5) using peptone water. A modified method of Gupta et al. (11) was used to detect phosphate solubilisation by inoculating the strains in modified Pikovskaya's agar containing the dye bromphenol blue $(0.4 \%)$. Nutrient broth amended with $2 \mathrm{mg} / \mathrm{ml}$ of L-tryptophan was used to detect IAA production as described by Bric et al. (2). Blue CAS agar plates containing iron CAS and HDTMA was used to detect the production of siderophores (34).

\section{Protease, starch, cellulase and pectinase, $\mathrm{HCN}$ and ACC deaminase activity}

Skim milk agar was used to detect protease activity, cellulase production was tested in M9 medium with $1 \%$ cellulose (22), synthesis of chitinase was determined in M9 medium containing $2 \%(\mathrm{w} / \mathrm{v})$ colloidal chitin (16), pectin agar plates were used to screen pectinase enzymes production, according to the method of Cattelan et al. (6) with Gram's iodine as the indicator. ACC deaminase activity was detected by using minimal medium (8) supplemented with ammonium sulphate $(2 \mathrm{~g}$ $\mathrm{L}^{-1}$ ) or $3 \mathrm{mM} \mathrm{ACC} \mathrm{(30)} \mathrm{as} \mathrm{the} \mathrm{substrate.} \mathrm{In} \mathrm{addition,} \mathrm{the}$ production of $\mathrm{HCN}$ was detected by the alkaline picrate test, as described by Bakker and Schippers (3).

\section{$16 S$ rRNA sequencing and phylogenetic analysis}

The genomic DNA was isolated by the QiAmp DNA mini kit method as per the manufacturer's protocol. The strain was identified using the 16S rRNA primers (F)-AGTTTGATCCTGGCTCAG and (R)ACGGCTACCTTGTTACGACTT. Amplification reactions contained 50 ng of genomic DNA, $1 \times$ Taq DNA polymerase buffer, $1 \mathrm{U}$ of Taq DNA polymerase, $0.2 \mathrm{mM}$ of each dNTP, $1.5 \mathrm{mM} \mathrm{MgCl}_{2}$ and $10 \mathrm{pM}$ of each primer. PCR was carried out in a Verti Thermo cycler (Applied Biosystems) at $95^{\circ} \mathrm{C}$ for $5 \mathrm{~min}$, followed by 30 cycles of $1 \mathrm{~min}$ at $95^{\circ} \mathrm{C}$, $1 \mathrm{~min}$ at $55^{\circ} \mathrm{C}$ and $2 \mathrm{~min}$ at $72^{\circ} \mathrm{C}$ with an extension of $72^{\circ} \mathrm{C}$ for $10 \mathrm{~min}$. The amplicons were visualised in a $1.2 \%$ agarose gel under a UV transilluminator. The PCR products were then sequenced in ABI PRISM Big Dye terminator cycle sequencing ready reaction kit on an $A B I$ Prism3100 Genetic Analyser. The sequence was edited using Chromas Lite 2.1. The sequence was compared using BLAST search in NCBI database. Phylogenetic analysis was performed using neighbour-joining method using the MEGA 6.06 software package (35) and bootstrapping was performed with 1,000 replicates.

\section{In vivo plant growth promotion traits}

\section{Seed source and disinfection}

Maize seeds of varF1 hybrid sweet corn (SUGAR-75) were used for the germination studies. Seeds were surface sterilized with $2 \%$ sodium hypochlorite solution for 2-3 min followed by several rinsing in sterile distilled water to remove the traces of sodium hypochlorite and dried at room temperature in laminar air flow for further studies.

\section{Seed germination studies}

\section{Paper towel method}

A loopful of the test strains was inoculated in nutrient broth and incubated at $37^{\circ} \mathrm{C}$ for $24 \mathrm{hrs}$ in an orbital shaker at $150 \mathrm{rpm}$ until the cells reached concentration of $1 \times 10^{8} \mathrm{cfu} / \mathrm{ml}$. Subsequently, seeds were soaked in bacterial inoculums for 2 to $4 \mathrm{~h}$ with occasional shaking (28) Seeds soaked in sterile nutrient broth served as control. Germination studies were carried out by the paper towel method (18). PGPR-treated seeds and control were seeded onto paper towels. Five seeds of maize were placed equidistantly on the moistened paper. Another pre-soaked paper towel was placed to hold the seeds in position. Towels were then rolled and placed in bottles filled with water to retain moisture and promote germination. The experiment was carried out in triplicates. After incubation for 15 days, the towels were unrolled and the seedlings were noted for the shoot and root length, number of shoots and roots, shoot and root fresh weight, dry weight and compared to the control.

\section{Preparation of the different formulations for field trials}

\section{Seed bacterization}

The test strains was inoculated in nutrient broth and incubated until it reached an O.D of $10^{8} \mathrm{cfu} / \mathrm{ml}$. The surface sterilized seeds were then soaked in the culture for 2-4 hrs with constant stirring. Seeds treated only with the nutrient broth served as control. The seeds were then dried in laminar air flow for 30 min before sowing in the fields (28).

\section{Carrier based formulations}

Three different organic carrier materials were used for the studies viz. talc, lignite and coir pith. These carrier materials were sterilized twice by autoclaving at $121^{\circ} \mathrm{C}$ for $15 \mathrm{~min}$ on two consecutive days before treating them with the bacterial cultures. The different formulations were prepared according to the method of Vidhyasekaran and Muthamilan (38). The test strains was inoculated in nutrient broth and incubated in an orbital shaker at $150 \mathrm{rpm}, 37^{\circ} \mathrm{C}$ for $24 \mathrm{hrs}$. To one $\mathrm{kg}$ of the carrier, $400 \mathrm{ml}$ of the bacterial suspension containing $10^{8} \mathrm{cfu} / \mathrm{ml}$ was mixed under aseptic conditions. After overnight drying under sterile conditions it was packed in sterile polythene bags and stored at room temperature.

\section{Field trials}

The field trials were performed in a randomized block design with three replicates of each treatment in a plot size of $10 \mathrm{~m} \times 10 \mathrm{~m}$. Each block had the following sets of treatments i) bacterized seeds ii) for the formulations soil amendment method using in furrow application where in $2 \mathrm{~g}$ of the formulation was put inside the furrow of $4 \mathrm{~cm}$ depth with the seeds placed above the formulation. Four seeds were placed per row with three rows per treatment. For the bacterized seeds, the seeds 
were treated with the culture, dried and placed in the furrows. Seeds without any treatment served as control. Irrigation whenever necessary was carried out. At the maturity stage ( $85^{\text {th }}$ day), the plants were harvested and number of leaves and roots, shoot and root length, shoot and root fresh weight and shoot and root dry weight and yield parameters (cob weight, cob length, number of rows per cob, grain weight) were recorded.

\section{Statistical analysis}

Two way ANOVA using Sidak multiple comparison test using GraphPad version 6.01 was carried out using triplicate value to identify significant difference in each vegetative parameter between treated and untreated seeds. All significant differences between treatments were expressed as $P$ values at 0.05 levels.

\section{Results}

\section{Identification and characterization of the strain F3-47}

On nutrient agar, the strains produced mucoid colonies with slight elevation and pigmentation. Morphologically, the strain was Gram negative, rod shaped and motile.16S rRNA sequencing of the F3-47

Table 1 Plant Growth Promoting and Biocontrol Traits of Pseudomonas indoloxydans F3-47

\begin{tabular}{|c|c|c|c|c|c|c|c|c|c|c|c|}
\hline $\begin{array}{l}\text { Strai } \\
\text { ns } \\
\text { No }\end{array}$ & $\begin{array}{l}\mathbf{N} \\
\mathrm{H}_{3}\end{array}$ & $\begin{array}{l}\text { PO } \\
4\end{array}$ & $\begin{array}{l}\text { IA } \\
\mathbf{A}\end{array}$ & $\begin{array}{l}\text { Si } \\
\text { d }\end{array}$ & $\begin{array}{l}\text { Prote } \\
\text { ase } \\
\text { activit } \\
\text { y }\end{array}$ & $\begin{array}{l}\text { Starch } \\
\text { Hydrol } \\
\text { ysis }\end{array}$ & $\begin{array}{l}\text { Cellul } \\
\text { ase } \\
\text { Activit } \\
\text { y }\end{array}$ & $\begin{array}{l}\text { Pectin } \\
\text { ase } \\
\text { activit } \\
y\end{array}$ & $\begin{array}{l}\mathrm{ACC} \\
\text { deamin } \\
\text { ase }\end{array}$ & $\begin{array}{l}\mathbf{H C} \\
\mathbf{N}\end{array}$ & $\begin{array}{l}\text { Chitin } \\
\text { ase }\end{array}$ \\
\hline F3 - & & & ++ & & & & & & & & \\
\hline 47 & ++ & + & + & - & ++ & ++ & + & ++ & ++ & + & - \\
\hline
\end{tabular}

,+++++ -strongly positive + -moderately positive, -- negative

$\mathrm{NH}_{3}$-ammonia, $\mathrm{PO}_{4}$-phosphate, IAA- Indole acetic acid, Sid- Siderophore

Table 2 Effect of seed inoculation with Pseudomonas indoloxydans strain on the vegetative parameters of maize seedlings (15 days)

\begin{tabular}{|l|l|l|}
\hline Parameters & Control & Test Strains \\
\hline No of leaves & $2 \pm 0$ & $2 \pm 0^{\mathrm{ns}}$ \\
\hline No of roots & $8 \pm 1$ & $12.66 \pm 0.57^{* * * *}$ \\
\hline Shoot length(cm) & $17.6 \pm 1.05$ & $25.80 \pm 1.57^{* * * *}$ \\
\hline Root length (cm) & $11.66 \pm 0.96$ & $14.76 \pm 0.51^{* *}$ \\
\hline Shoot fw(mg) & $442.36 \pm 27.12$ & $533.7 \pm 56.84^{*}$ \\
\hline Root fw(mg) & $145.11 \pm 18.29$ & $217.76 \pm 27.93^{\mathrm{ns}}$ \\
\hline Shoot dw(mg) & $24.83 \pm 3.03$ & $38.22 \pm 5.01^{* *}$ \\
\hline Root dw(mg) & $13.33 \pm 1.89$ & $18.31 \pm 3.02^{\mathrm{ns}}$ \\
\hline
\end{tabular}

ns $p>0.05$ non-significant as compared to control, ${ }^{*} p \leq 0.05$ significant at $5 \%$ as compared to control, ${ }^{* *} p \leq 0.01$ significant at $1 \%$ as compared to control, ${ }^{* * *} p \leq 0.001$ significant at $0.1 \%$ as compared to control, ${ }^{* * *} p \leq 0.0001$ significant at $0.01 \%$ as compared to control. Values are the mean of triplicates with standard deviation of mean. 


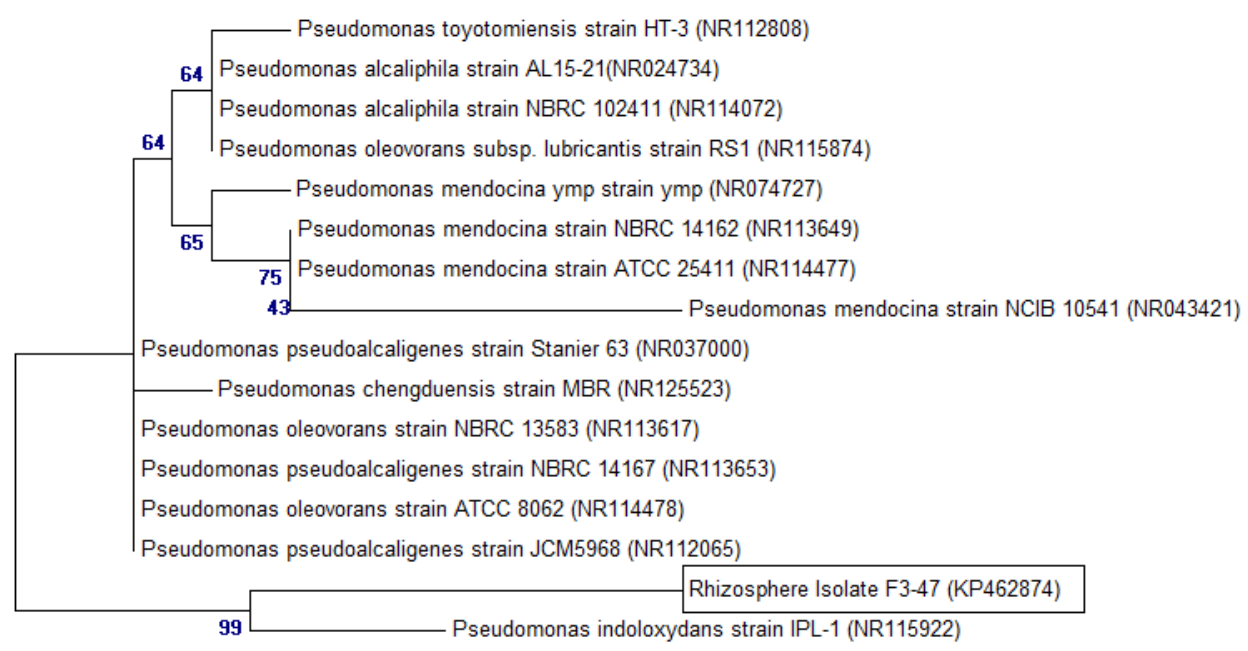

Fig 1 Phylogenetic tree based on 16S rRNA sequences from related species of the genus Pseudomonas constructed using the neighbor-joining method with 1,000 bootstrap replicates.
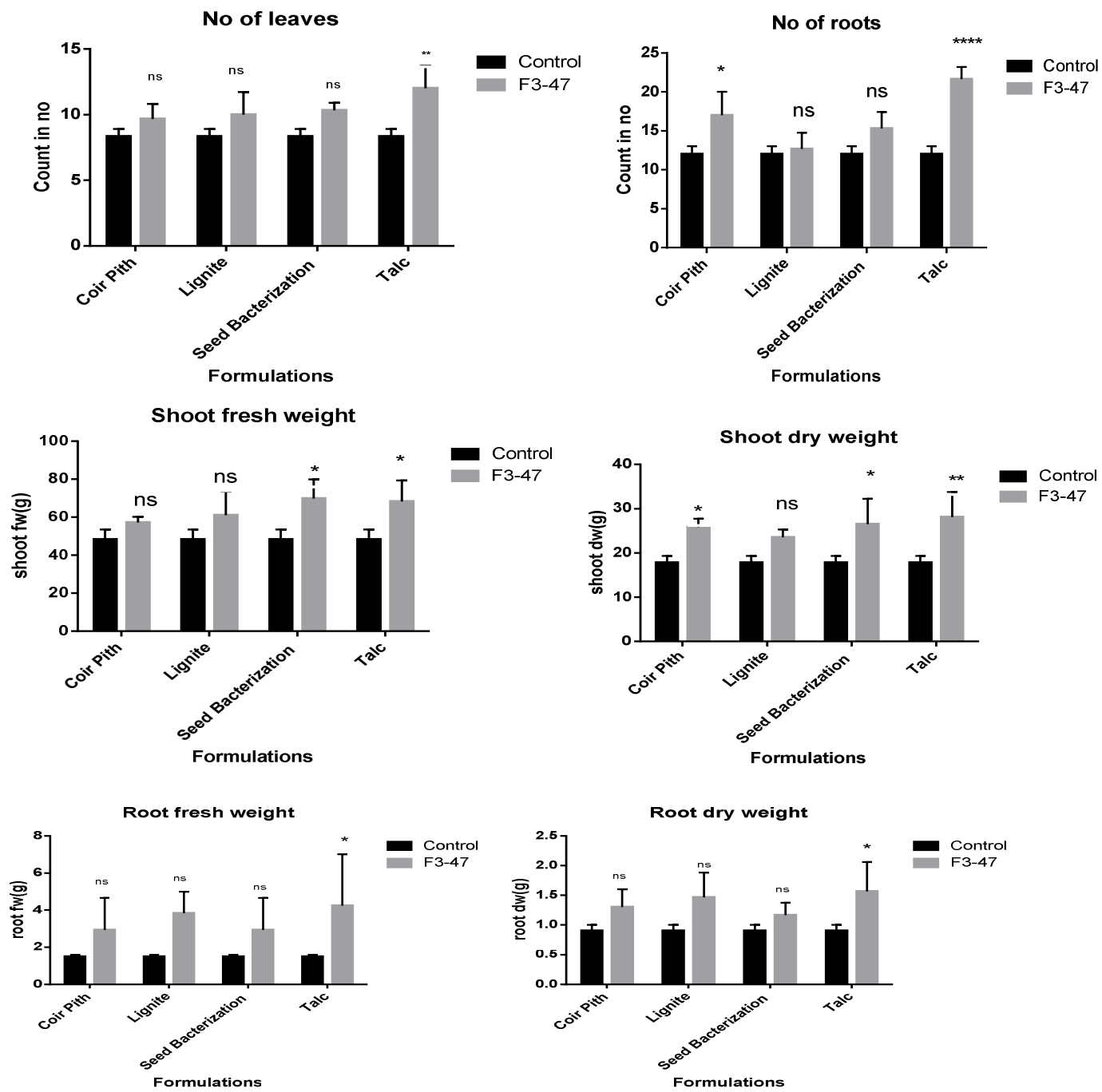

Figure 2. Effect of the bioinoculant formulations on the growth response of maize under field trials Data represents mean value \pm S. $D$ ns ( $p$ value greater than 0.05) Nonsignificant as compared to control (ANOVA).

* ( $p$ value between 0.05 and 0.01) Significant at $5 \%$ (ANOVA).

$* *$ ( $p$ value between 0.01 and 0.001$)$ Significant at $1 \%$ as compared to control (ANOVA)

$* * *$ ( $p$ value less than 0.001$)$ Significant at $0.1 \%$ as compared to control (ANOVA). 

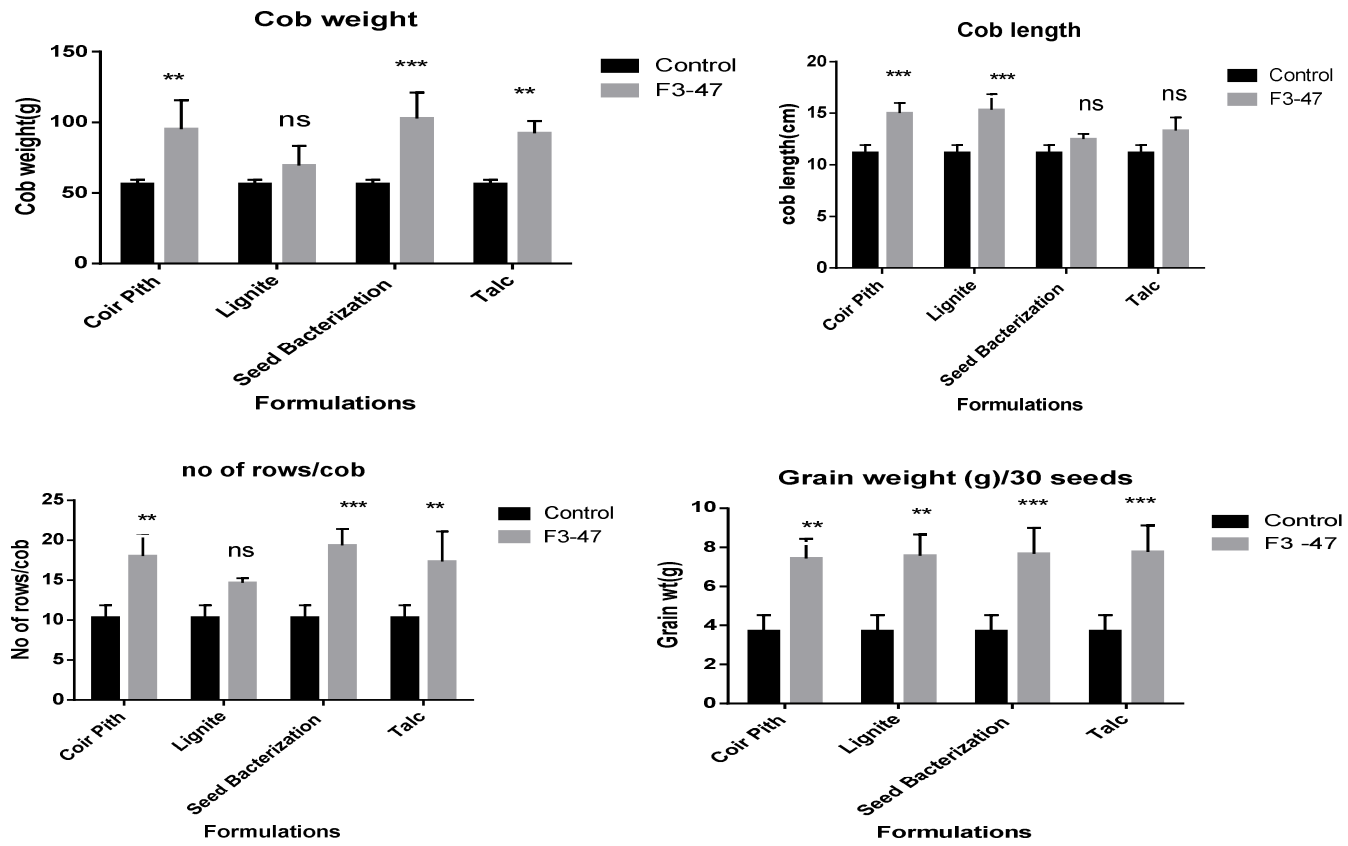

Figure 3. Effect of the inoculation of the different bioformulations on the yield parameters of maize Data represents mean value \pm S.D ns ( $p$ value greater than 0.05 ) Nonsignificant as compared to control (ANOVA)

* ( $p$ value between 0.05 and 0.01 ) Significant at $5 \%$ (ANOVA)

** ( $p$ value between 0.01 and 0.001 ) Significant at $1 \%$ as compared to control (ANOVA)

$* * *$ ( $p$ value less than 0.001 ) Significant at $0.1 \%$ as compared to control (ANOVA)

strains showed maximum homology with Pseudomonas indoloxydans strain IPL-1. The sequence data has been submitted in the NCBI database under the accession number KP462874 (Figure 1).

\section{In vitro plant growth promoting and biocontrol traits}

The strain was able to produce ammonia, indole acetic acid and was able to hydrolyse phosphate, starch and casein. It produced the hydrolytic enzymes like cellulase and pectinase indicating its potential as a biocontrol agent. The strains showed a good growth in DF medium supplemented with ACC as compared to growth on $\left(\mathrm{NH}_{4}\right)_{2} \mathrm{SO}_{4}$ and medium without nitrogen source indicating it as a producer of ACC deaminase as well. Production of $\mathrm{HCN}$ changing the color of the filter paper to brown saturated with picric acid (Table 1) was noticed.

\section{Seed germination studies}

The effects of the strains on the germination of maize seeds over the control were studied by evaluating the morphometric parameters. It showed a significant increase in the number of roots (58\%), shoot (32\%) and root length $(27 \%)$. There was as a significant increase in shoot fresh weight of (20\%) and dry weight of $(54 \%)$ as compared with the control. Considerable increase in root weight was also noticed than the uninoculated control (Table 2).

\section{Field trials}

In general, there was an increase in the growth of the treated plant as compared to the control. A two way ANOVA was performed to see the effects of the different carriers on plant growth responses (Figure 2). The talc based formulation showed a significant increase in the number of leaves as compared to control. There was a significant increase in the number of roots with coir pith and talc formulations. Lignite and talc based formulations displayed a significant increase in the shoot fresh weight. Though the root fresh weight was higher as compared to control in all the treatments it was not significant. Similarly, significant increase in the shoot and root dry weight was observed in treated plants as compared to the untreated plants.

Treatment effects on cob weight, number of grains per cob, cob length and grain weight are depicted in Figure 3. Seed bacterization using bacterial formulation showed a significant increase $(82 \%)$ in the cob weight when compared with carrier based formulations. The increase in the length of the cob was prominent in the lignite based formulation as compared to the control. Irrespective of the formulations all treatments showed a significant increase in the number of rows per cob and grain weight when compared to uninoculated control seeds.

\section{Discussion}

Bacteria generally belonging to the genera Azotobacter, Azospirillum, Bacillus, Bradyrhizobium, 
Enterobacter, Pseudomonas, etc. are reported as the potent PGPR strains in the field of bio fertilization and biocontrol (37). Among these the genus Pseudomonas is widely used a PGPR due to its multiple mechanism of action as plant growth promoting and biocontrol agent. Different species of Pseudomonas like P.putida, P.flourescens, $P$. aeruginosa and P.aurefaciens are widely used as biocontrol agents (19) but little or no work has been reported on the role of P.indoloxydans as a PGPR agent.

Hence, the present study was focused on the isolation and characterization of the rhizosphere strains belonging to Pseudomonas indoloxydans for the plant growth promoting and biocontrol traits. The strain was positive for ammonia, IAA, ACC deaminase, phosphate etc proving it as a good PGPR. IAA is the phytohormone known to enhance the growth of the plant in terms of root and shoot length (1). It is reported that $P$. fluorescens CHAO can produce around $32 \mathrm{mg} \mathrm{ml}-1$ of IAA and $P$. putida can produce up to $24 \mathrm{mg} \mathrm{ml}-1$ of IAA (12). The PGPR can solubilise the insoluble tri calcium phosphate and make it available to plants that are generally recalcitrant to be solubilised by the plants alone (26). Pseudomonas and Bacillus are reported to be the main phosphate solubilizers (36). The strains turned the color of the peptone water to yellow upon the addition of Nessler's reagent indicating ammonia production which is an intermediate in biological nitrogen fixation. The studies are reconfirmed with $95 \%$ of strains of Bacillus and Pseudomonas (94.2\%) as potent ammonia producers (21). The strains was able to hydrolyse ACC causing deamination of ACC by the enzyme leading to lowering of plant ethylene level and thereby forming longer roots. The strains were able to produce hydrogen cyanide (HCN) a unique trait of Pseudomonas sp., a volatile secondary metabolite known to negatively affect root metabolism and growth (33) for biological control of weeds (15).

Biofertilizers and biopesticides are usually prepared as carrier based inoculants containing live microorganisms as the cell suspensions may not be viable under field conditions. Carriers used in the present study increased the survival rate of the inoculum by protecting it from dessication and death (14). The carriers and the inoculums were mixed at the ratio of $1: 4$ as reported by Krishnamurthy and Gnanamanickam (25) who developed talc based formulation of $P$. fluorescens for the management of rice blast caused by Pyricularia grisea. Similarly, lignite and coir pith based formulations were also prepared in a manner similar to the talc and peat based formulations of Pseudomonas and Bacillus for the management of turmeric rhizome rot (27).

The results of field trial revealed that inoculation of the maize seeds with the different formulations of Pseudomonas indoloxydans F347 was effective in significantly increasing the root and shoot length (20-44\%) as well as the yield parameters (cob weight, cob length, number of rows per cob) in maize. Increased root length, shoot length, biomass, and various other vegetative parameters of the maize plant treated with Pseudomonas indoloxydans F3-47 based bio-formulations were due to the entire plant growth promoting traits tested positive in vitro. The test strain was able to solubilise phosphate indicating its application in phosphorus poor soil as reported by Krey et al. (24) who studied the effect of PGPR on phosphorus nutrition and observed that the field application of $P$. fluorescens DR54 on maize increased plant growth and soil $\mathrm{P}$ pools. Strain F3-47 produced ammonia indicating its role in nitrogen fertilization. Rosas et al. (32) studied the promotion effect of Pseudomonas aurantiaca SR1 on maize and wheat in field treatments that included phosphorus and nitrogen fertilization. Both crops, when inoculated with the SR1 strain, presented significant promoting effect in growth parameters and higher yields with lower fertilization doses than conventionally applied. The highest increase of $53.72 \%$ and $108.71 \%$ for shoot and root biomass respectively was obtained in maize plants inoculated with a combination of $P$. fluorescens- $P$. putida as reported by Gholami et al. (10). The test strain in the form of different formulations also showed a significant increase in the plant biomass as compared to control.

\section{Conclusion}

This study identifies and harnesses the potential of a native microbial strain Pseudomonas indoloxydans F3-47 as a plant growth promoting and biocontrol agent. Among the different carrier based formulations of the test strains all the formulations showed a significant increase in the morphometric paramteters and yield as compared to the untreated control seeds. Though different formulations based on Pseudomonas strains are reported, the present work with $P$. indoloxydans F3-47 being a novel strain of agricultural field regains the importance. Hence, the development of a versatile bioformulation based on the indigenous strain of $P$. indoloxydans F3-47 producing a variety of secondary metabolites is a viable alternative to the chemical methods of fertilization and pest control in agriculture.

Acknowledgments This work was supported by Department of Biotechnology, Government of India, New Delhi under the grant [BT/PR4683/AGR/21/353/2012]. Thanks are due to Karunya University for the support extended during the study.

\section{References}

1. Aloni, R., Aloni, E., Langhans, M., \& Ulrich, C.I. (2006). Role of cytokinin and auxin in shaping root architecture: regulating vascular differentiation, 
lateral root initiation, root apical dominance and root gravitropism. Ann. Bot., 97: 883-893.

2. Avis, T.J., Gravel, V., Antoun, H., \& Tweddell, R.J. (2008). Multifaceted beneficial effects of rhizosphere microorganisms on plant health and productivity. Soil Biol. Biochem, 40: 1733-1740.

3. Bakker, A.W., \& Schippers, B. (1987). Microbial cyanide production in the rhizosphere in relation to potato yield reduction and Pseudomonas spp.mediated plant growth-stimulation. Soil Biol. Biochem, 19: 451- 457.

4. Brick, J. M., Bostock, R. M., Silverstone, S. E. (1991). Rapid in situ assay for indole acetic acid production by bacteria immobilized on nitrocellulose membrane. Appl.Environ. Microbiol, 57: 535-538.

5. Cappuccino, J.C., and Sherman, N. (1992). Microbiology: A Laboratory Manual ( $3^{\text {rd }}$ edition, pp 125-179) Benjamin/ Cummings, NY.

6. Cattelan, A. J., Hartel, P. G., \& Furhmann, F. F. (1999). Screening for plant growth promoting rhizobacteria to promote early soybean growth. Soil Sci Soc Am, 63: 1670-1680.

7. De Cal, A., Sztejnberg, A., Sabuquillo, P., and Melgarejo, P. (2009). Management of Fusarium wilt on melon and watermelon by Penicillium oxalicum. Biol. Control, 46: 267-278.

8. Dworkin, M., and Foster, J.W. (1958). Experiments with some microorganisms which utilize ethane and hydrogen. J. Bacteriol, 75: 592-601.

9. Ganeshan, G., and Kumar, M. A. (2005). Pseudomonas fluorescens, a potential bacterial antagonist to control plant diseases. J Plant Interact., 1(3): 123-134.

10. Gholami, A., Shahsavani, S., and Nezarat, S. (2009). The Effect of Plant Growth Promoting Rhizobacteria (PGPR) on germination, seedling growth and yield of maize. World Acad Sci Eng Technol , 49: 19-24.

11. Gupta, R., Singh, R., Sanker, A., Chandra, R. M., and Kumar, R. S. (1994). A modified plate assay for screening phosphate solubilizing microorganisms. J Gen Appl Microbiol, 40: 255-60.

12. Haas, D., and De'fago, G. (2005). Biological control of soil-borne pathogens by fluorescent $P$ seudomonas. Nat. Rev. Microbiol., 3(4): 307-319.

13. Haas, D., and Keel, C. (2003). Regulation of antibiotic production in root-colonizing Pseudomonas spp. and relevance for biological control of plant disease.
Annu Rev Phytopathol, 41:117-153.

14. Heijnen, C. E., Burgers, S. L. G. E., and van Veer, J. A. (1993). Metabolic activity and population dynamics of rhizobia introduced into unamended and betonite amended loamy sand. Appl.Environ. Microbiol, 59: 743-747.

15. Heydari, S., Moghadam, P.R., and Arab, S.M. (2008). Hydrogen cyanide production ability by Pseudomonas fluorescens bacteria and their inhibition potential on weed. Competition for Resources in a Changing World: New Drive for Rural Development, Tropentag, Hohenheim.

16. Hsu, S. C., and Lockwood, J. L. (1975). Powdered Chitin Agar as a Selective Medium for Enumeration of Actinomycetes in Water and Soil. J Appl Microbiol, 29: $422-426$.

17. Huang, X., Zhang, N., Yong, X., Yang, X., and Shen, Q. (2011). Biocontrol of Rhizoctonia solani damping-off disease in cucumber with Bacillus pumilus SQR-N43. Microbiol. Res., 167: 135-43.

18. ISTA, (1993). Proceedings of the international Seed Testing Association, International Rules for Seed Testing. Seed Science Technology. 21: 25-30.

19. Jan, A.T., Azam, M., Ali, A., and Haq, Q. (2011). Novel approaches of beneficial Pseudomonas in mitigation of plant diseases -an appraisal. J Plant Interact, 6(4): 195-205.

20. Jenni, B., Isch, C., and Aragno, M. (1989). Nitrogen fixation by new strains of Pseudomonas pseudoflava and related bacteria. J. Gen. Microbiol., 135, 461467.

21. Joseph, B., Patra, R., and Lawrence, R. (2007). Characterization of plant growth promoting Rhizobacteria associated with chickpea (Cicer arietinum L.). Int. J. Plant Prod, 1(2): 141-152.

22. Kasana, R., Salwan, C. R., Dhar, H., Dutt, S., and Gulati, A. (2008). A rapid and easy method for the detection of microbial cellulases on agar plates using Gram's lodine. Curr. Microbiol., 57: 503507.

23. Kloepper, J.W., and Schroth, M. N. (1978). Plant growth promoting rhizobacteria on radishes. Proceedings of the Fourth International Conference on Plant Pathogen Bacteria, 2: 879-882.

24. Krey, T., Vassilev, N., Baum, C., EichlerLöbermann, B. (2013). Effects of long-term phosphorus application and plant-growth promoting 
rhizobacteria on maize phosphorus nutrition under field conditions. Eur. J. Soil Biol., 55: 124-30.

25. Krishnamurthy, K., and Gnanamanickam, S. S. (1998). Biological control of rice blast by Pseudomonas fluorescens strain Pf7-14: Evaluation of a marker gene and formulations. Biol. Control, 13: 158-165.

26. Mehta, S., and Nautiyal, C.S. (2001). An efficient method for qualitative screening of phosphatesolubilizing bacteria. Curr. Microbiol., 43: 51-56.

27. Nakkeeran, S., Kavitha, K., Mathiyazhagan, S., Fernando, W. G. D., Chandrasekar, G., and Renukadevi, P. (2004). Induced systemic resistance and plant growth promotion by Pseudomonas chlororaphis strain PA-23 and Bacillus subtilis strain CBE4 against rhizome rot of turmeric (Curcuma longa L.). Can. J. Plant Pathol., 26:417-418.

28. Nandakumar, R., Babu, S., Viswanathan, R., Raguchander, T., and Samiyappan, R. (2001). Induction of systemic resistance in rice against sheath blight disease by plant growth promoting rhizobacteira. Soil Biol. Biochem, 33: 603-612.

29. Patten, C.L., and Glick, B. R. (2002). Role of Pseudomonas putida indole acetic acid in development of the host plant root system. Appl. Environ. Microbiol, 68: 3795-3801.

30. Penrose, D.M., and Glick, B.R. (2003). Methods for isolating and characterizing ACC deaminasecontaining plant growth-promoting rhizobacteria. Physiol. Plant, 118: 10-15.

31. Richardson, A. E. (2001). Prospects for using soil microorganisms to improve the acquisition of phosphorus by plants. Aust. J. Plant Physiol., 28: 897-906.

32. Rosas, S.B., Avanzin, G., Carlier, E., Pasluosta. C., Pastor, N., and Rovera, M. (2009). Root colonization and growth promotion of wheat and maize by Pseudomonas aurantiaca SR1. Soil Biol. Biochem, 41: 1802-6.

33. Schippers, B., Bakker, A., Bakker, P., and van Peer, R. (1990). Beneficial and deleterious effects of $\mathrm{HCN}$-producing pseudomonads on rhizosphere interactions. Plant Soil, 129 (Suppl 1): 75-83.

34. Schwyn, B., and Neilands, J. B. (1987). Universal chemical assay for the detection and determination of siderophores. Anal. Biochem, 160: 47-56.

35. Tamura, K., Peterson, D., Peterson, N., Stecher, G., Nei, M., and Kumar, S. (2011). MEGA5: Molecular
Evolutionary Genetics Analysis using maximum likelihood, evolutionary distance, and maximum parsimony methods. Mol Biol Evol, 28: 2731-2739.

36. Tilak, K.V.B.R., Ranganayaki, N., Pal, K.K., De, R., Saxena, A.K., Nautiyal, C.S., Mittal, S., Tripathi, A. K., and Johri, B. N. (2005). Diversity of plant growth and soil health supporting bacteria. Curr. Sci, 89: 136-150.

37. Vessey, J.K. (2003). Plant growth promoting rhizobacteria as biofertilizers. Plant Soil, 255:571586.

38. Vidhyasekaran, P., and Muthamilan, M. (1995). Development of a formulation of Pseudomonas fluorescens for control of chickpea wilt. Plant Dis.. 79: 782-786.

39. Wackett, L.P. (2000). Pseudomonas entering the post-genomic era. Environ. Microbiol., 2: 348-354. 